\title{
Design and Validation of an Instrument to Measure Educational Innovations in Primary and Pre-Primary Schools
}

\author{
María Ángeles Turrado-Sevilla ${ }^{1} \odot$ and Isabel Cantón-Mayo ${ }^{2} \odot$ \\ ${ }^{1}$ Facultad de Humanidades y Ciencias Sociales, Universidad Isabel I, Spain \\ ${ }^{2}$ Facultad de Educación, Universidad de León, Spain
}

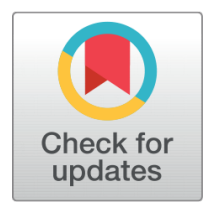

Received 2021-02-15
Revised 2021-03-04
Accepted 2021-05-28
Published 2022-01-15

Corresponding Author María Ángeles Turrado-Sevilla, mariaangeles.turrado@ui1.es

Despacho 145, Facultad de Educación, Universidad de León, 24071, León, Spain.

DOI https://doi.org/10.7821/ naer.2022.1.727

Pages: 79-96

Distributed under CC BY-NC 4.0

Copyright: () The Author(s)

\section{ABSTRACT}

The creation and implementation of innovation proposals in education can provide a new key towards sustainable development. We are aware that schools perform very different innovations but often, with very low levels of impact and dissemination in their community. There are not many studies that describe, put a value on, categorize or analyse the innovations. This study sought to gain insight into the ICT innovations produced in Spanish primary and pre-primary schools. A quantitative approach based on a questionnaire was used to collect the data, named MANEDUIN, completed by 86 teachers selected by stratified random sampling (public - private, rural - urban). The reliability and the construct-related validity was evaluated from the questionnaire and the validity of content decided by means of experts' judgment. Our findings point to a good consistency in the questionnaire (Cronbach's Alpha: 0.848). The descriptive statistics and the analysis were made by factorial categories. The results of the factorial analysis confirm the dimensions proposed in the design of the questionnaire in the categories of the factors included in the innovation (social cohesion, interaction with the community, technologies, and success), the innovative schools and their characteristics, the topic and the type of innovation (on resources, direction, materials and time), as well as the obstacles to the innovation. This paper concludes that the questionnaire MANEDUIN is a valid and reliable tool to measure the management of schools' innovations.

\section{Keywords INNOVATION, EDUCATIONAL MANAGEMENT, ICT, TEACHER EFFECTIVENESS, PRIMARY SCHOOL}

\section{INTRODUCTION}

Market globalization, the surge of information technology in almost all facets of life, the competitiveness of world powers, migration and demographic changes are some of the reasons that have made innovation a priority not just for businesses but also for educational institutions. Innovations created by teachers, teacher communities and schools in their

\section{OPEN ACCESS}


daily practice play a crucial role in improving the quality and effectiveness of education systems (Halász, 2021). Citizens of the 21st century need to develop competences so that they can participate in social inclusion, and evolve, both personally and professionally, in a digital society (Rodríguez, Cantabrana, \& Cervera, 2021), bearing in mind, that digital competence is one of the key competences (Muñoz-Repiso, Martín, \& Gómez-Pablos, 2020). Recent research shows the need for a change in the educational paradigm, where education is conceived as a place of lifelong learning, and not a rigid school that conceives educational success as performance of exams (Rochovská, Droščák, \& Šilonová, 2020).

Thus, in order to improve student learning outcomes, new pedagogies and teaching approaches must emerge (Bakhru, 2018). In this regard, we are fully aware that an increase in the proliferation and management of ICT educational innovations is already happening in most schools (Almandoz, 2008). Such experiences often take place in many schools, but sometimes they are not recognized or are simply ignored outside the classroom or the school where they took place. Teachers and school managers are reluctant in some cases to disclose their innovative practices, sometimes because they themselves still doubt their value, but often because they may not have the time to get the message out (Licht, Tasiopoulou, \& Wastiau, 2017). Its study, besides, has traditionally remained under-researched. Accordingly, we consider it is necessary to spread these initiatives and also to characterize teachers and schools (or other innovation agents) that encourage changes for the improvement of education (Turrado-Sevilla, Mayo, \& Lucía, 2020).

A few years ago Cerrillo (2000), pointed out that each community fully integrates a set of talent banks unexplored by its educational institutions. In the same way Batllé (2015), admits without reservation, that teachers do and manage great things in unjust anonymity. Similarly, Carbonell (2015, p. 18) states that:

Some utopias are already being developed today in many schools and other learning spaces. Although these innovations always require renewal, enrichment and consolidation, they serve as a beacon for a lot of educators who think and struggle every day to make a reality the dream of an innovative, socially equitable, culturally powerful and totally free education. That is, EDUCATION in capital letters.

Innovation management is a complex process and includes the set of innovation tools, the different phases, the definition of the organizational structure, the forecast of resources for innovation, the definition of the policy and objectives of innovation and the methods of evaluation and monitoring of the system itself. It requires a continuous and deliberate change in the scope and actions to improve the elements, the participants, the organization and the management of education. Innovation is at the essence of education and the science of education (Ramírez-Montoya, 2020).

This issue has been internationally studied in a number of studies (Berrocoso, Arroyo, \& Diaz, 2010; Bocconi, Kampylis, \& Punie, 2012; Halász, 2021; Law, Yuen, \& Fox, 2011; OECD, 2013, 2017; Paniagua \& Istance, 2008; Rikkerink, Verbeeten, Simons, \& Ritzen, 2016; Vincent-Lancrin, Urgel, Kar, \& Jacotinet, 2019). The studies at the national level (Marcelo et al., 2009) and by communities (Gairín, Armengol, \& Moreno, 2010; 
Jauregui \& P, 2010; Jauregui, Vidales, \& K, 2012; Tójar \& Mena, 2011) have an impact on the same lack of systematization, collection, management and classification of innovations. In fact, in Castile and Leon (one of the communities in Spain with the most active teachers) there is only one pilot study of innovation management in Zamora and Salamanca (Martín, González, \& Costillas, 2013), which uses only qualitative tools, interviews, as a way of evaluating innovation management. Thus, despite the increase in management of these experiences that is taking place, at the national and international levels, currently there is no consensual or shared evaluation model that would allow us to advance the knowledge, management and improvement of these experiences (Tójar \& Mena, 2011). There is a lack of cross-validated instruments of measurement that are a conceptual fit with the innovation literature, which challenges our common understanding of what causes innovations in schools to ultimately fail or succeed (Lambriex-Schmitz, Van Der Klink, \& Beausaert, 2020). Besides, designing new questionnaires is complicated and time consuming, therefore it is tempting to use and re-use existing samples for practical and legitimation reasons (Scherbaum \& Meade, 2009)

This article makes a contribution to the literature on the educational innovations by developing and validating a multidimensional, reliable instrument to measure management of schools' innovations. We chose primary and pre-primary levels since according to the authors, there is always a greater willingness among primary school teachers over secondary school teachers to innovate (Cuenca, Gorospe, Aberasturi, \& Etxebarria, 2009; Evans \& Leppmann, 1970; Gibbons \& Silva, 2011; Hoffman \& Holzhuter, 2012; Marcus, 2012; Serdyukov, 2017).

\section{MATERIAL AND METHODS}

While sometimes it is not simple to differentiate clearly between the many different forms of innovation, several authors have developed a number of categorizations. An interesting suggestion that we will use in this investigation (Tójar \& Mena, 2011) is which differentiates between two sorts of educational innovations: vertical (top-down) and horizontal (bottom-up). Descending innovations are promoted by the authorities in charge of education (national or regional authorities) and imply a process of transforming in order to introduce organizational, academic or structural modifications. Bottom-up innovations, on the other hand, are implemented by the teachers directly and take place at the individual classroom or school level. Once grassroots innovations are created, they can be generalized or extended to other levels, strengthening their adoption to the point of becoming institutionalized, even at deep structural levels.

In this way, our questionnaire focuses on exploring these two constructs in order to gain insight into innovations management and to know which one is more likely to achieve success. 


\subsection{Questionnaire Validation}

The developed questionnaire was first validated by a panel of experts (Aguilar, Eduardo, \& Berganza, 1996; Wiersema, 2001), by means of asking their opinion on three criteria of the questionnaire: relevance, pertinence and univocity.

The panel of judges was comprised of three university professors, two primary school teachers, a headmaster of a primary school and an education inspector. Each of them was contacted personally and subsequently received an e-mail explaining the objectives of the research as well as requesting their good judgment in evaluating the effectiveness of the questionnaire in its application. Accompanying the questionnaire, they received a template to evaluate each of the variables in the questionnaire with the criteria of relevance and univocity. In addition, the possibility to make any observation or modification they considered necessary on any aspect relating to the questionnaire in each of the variables (Table 1) was left open for them.

\begin{tabular}{lllll}
\hline \multicolumn{1}{l}{ Table 1} & External grid model of annotations for expert judgment \\
& Univocity & Pertinence & Relevance & Comments (Suggestions, corrections) \\
\hline General data & 1234 & 1234 & 1234 & \\
Variable 1 & & & & \\
Variable 2 & & & & \\
\hline
\end{tabular}

Once the answers obtained by the experts had been analysed, the following validity criteria were established to determine whether each of the variables should be maintained, improved or eliminated (Table 2).

Table 2 Validity criteria for the variables evaluated by the experts

\begin{tabular}{lll} 
STEP & Elimination criteria & $\begin{array}{l}\text { Nu } \\
\text { elim }\end{array}$ \\
\hline 1 & $\begin{array}{l}\text { At least 1 person classifies it } \\
\text { as non-univocal }\end{array}$ & 19 \\
2 & $\begin{array}{l}\text { At least 1 person classifies it } \\
\text { as non-pertinent }\end{array}$ & 31 \\
3 & $\begin{array}{l}\text { At least 1 person classifies it } \\
\text { as non-relevant }\end{array}$ & 25 \\
\hline
\end{tabular}

Number of Eliminated variables eliminated variables

$1937,40,41,44,49,50,51,53,77,79,83,92,111,119,123,147,157,168,160$

$3123,28,30,38,43,45,46,60,61,63,65,78,82,84,91,101,104,110,112,135,141$, $145,149,153,154,155,156,163,164,165,166$

$22,24,29,31,36,42,52,62,71,71,72,73,76,94,97,98,102,105,122,128,144$, $146,159,167,176$

\subsection{Final Preparation: Final Version of the Questionnaire}

In this way, the final model of the questionnaire "Analysis of the management of ICT innovations in nursery and primary education schools in the region of León" (MANEDUIN) was definitely designed with the next 13 dimensions: topic and reasons, type, approach, time devoted to innovation, resources, outside support, assessment, obstacles, satisfaction, impact and dissemination (Table 3).

Using random stratified sample, a reliability level of $95.5 \%(2 \sigma)$ and a margin of bias of $+5 \%$ was obtained, so that a required sample size of at least 71 subjects was calculated. 
Table 3 Dimensions of the definitive version of thequestionnaire "Analysis of innovations in primary and pre-primary schools"

\begin{tabular}{ll} 
Categories & Variables \\
\hline General aspects & $1,2,3,4,5,6,7,8,9,10,11,12$ \\
Topic and reasons for innovation & $13,14,15,16,17,18,19,20,21,22,23,24,25,26,27,28,29$ \\
Type of innovation & $30,31,32,33,34,35,36$ \\
Approach & $37,38,39,40,41,42,43,44,45,46,47,48,49,50,51,52,53$ \\
Time devoted to innovation & $54,55,56,57$ \\
Resources & $58,59,60,61,62,63,64,65,66,67,68,69,70,71,72,73$ \\
Outside support & $74,75,76,77,78$ \\
Assessment & $79,80,81,82,83,84,85,86,87,88,89,90$ \\
Obstacles & $91,92,93,94,95,96,97,98,99$ \\
Satisfaction & $100,101,102,103,104$ \\
Impact & $105,106,107,108,109,110$ \\
Dissemination & $111,112,113,114$ \\
Others & 115 \\
\hline
\end{tabular}

Data gathering was conducted during the months of May and June 2018. The sample was intentional and convenient since an online Google Docs questionnaire for teachers was sent by email to all of them. It was specified that in the event that several teachers carried out the same project, only one questionnaire would be completed for each innovation. The online questionnaire was answered by 32 primary and pre-primary education teachers from the Province of León. In addition, the questionnaire was also sent through social networks and was additionally attended in person by different schools in the province. After the data collection process, the final sample consisted of 86 teachers.

Its reliability and internal consistency were assessed through the Cronbach Alpha coefficient, which is one of the most used by researchers' reliability indices (Ledesma, Ibañez, \& Mora, 2002). 12 variables were inverted in order to guarantee all the variables in each of the scales have the same sense of response. Since the purpose of this coefficient is to determine the relationship between variables, an analysis was carried out to evaluate the consistency for the entire questionnaire. A second analysis was performed to divide the sample into two parts following the technique of the two halves. George and Mallery (2003) determine the following Cronbach's Alpha coefficient-based scale to rate the instrument's reliability: Excellent: >0.90, Good: 0.81-0.90, Acceptable: 0.71-0.80, Questionable: 0.61-0.70, Poor: $0.51-0.60$, Unacceptable: $<0.50$. The instrument has a reliability of 0.848 .

Also, to reduce the questionnaire's dimensionality we conducted an exploratory factor analysis (Ortega, Sicilia, \& González-Cutre, 2013) of each of the questionnaire dimensions to to find those variables that are grouped together with a common meaning and, in this way, to try to understand and analyse the structure of the interrelationships among variables that define the management of educational innovations in primary and pre-primary schools.

This analysis is a dimensionality reduction technique that groups correlated variables into sets called factors. Principal Component Analysis was used as an extraction method with the aim of creating a linear combination that explains the highest possible percent- 
age of variance, at least $60 \%$ of the total variance. First, the matrix of correlations of the variables, the communalities (percentage of the variance that can be explained by the factorial model), the Kaiser-Meyer-Olikin index (KMO) and the Bartlett spherical test were calculated to check whether the data had the right characteristics to carry out this analysis (Frías-Navarro \& Soler, 2012). The KMO index was used to check if the partial correlations between the variables were small enough. This parameter can take values between 0 and 1 , the closer to 1 the value is, the more meaningful the factorial analysis will be. An index lower than 0.5 indicates that this analysis should not be used with the sample being evaluated. In addition, Bartlett's spherical test was applied to test the invalid hypothesis that the correlation matrix is an identity matrix and therefore there would be no correlation between variables, making factorial analysis meaningless. Secondly, the determination of the number of factors to be kept in the analysis was made. There are various criteria to proceed in this way, but one of the most widely used is Kaiser's rule: "retain those factors whose eigenvalues are greater than one" (Jimenez, Flores, Gómez, \& G, 2000). However, since these criteria tend to overestimate the number of factors, the sedimentation plot (Cattell, 1966) was also examined by identifying the turning point at which the slope of the line connecting the ordered factors ceases to decrease, including in the final analysis only the factors prior to this one. Likewise, Ferrando and Anguiano-Carrasco (2010) indicate that the minimum number of factors is determined by the number of variables, the minimum necessary number of these being a third or a fifth of the number of variables. A factor rotation was then performed following the Varimax rotation method with Kaiser normalisation to improve the interpretation of the factor structure. This procedure is useful if a variable is assigned a similar weight in two factors and because in the original factorial solution (always orthogonal) the unrotated factors are always dependent on each other. As for the criteria for interpreting the saturation of a variable, the minimum value was defined as 0.5 to be included within the factor (Jimenez et al., 2000). If a variable is within two different factors, it will be included in the factor in which it has the greatest weight. Finally, once the variables assigned to each factor were determined, each factor was named.

All the statistical analyses were carried out with Stata (version 13, Stata Corp, College Station, TX) and IBM SPSS 22 (SPSS, INC., Chicago, IL) designed for Mackintosh. Statistical significance was established at $\mathrm{P} \leq 0.05$. For purposes of simplicity, only $\mathrm{P}$ values that indicate a significant difference are presented.

\section{RESULTS}

\subsection{Cronbach's Alpha Results}

The following table (Table 4) presents the results of the evaluation of the internal consistency of the questionnaire by means of the Cronbach's Alpha coefficient.

Regarding the psychometric aspects of the questionnaire, the analysis revealed a good consistency of the questionnaire following the criteria established by George and Mallery (2003) since the coefficient was 0.848. Likewise, the results were replicated through the analysis of the technique of the two halves, obtaining in one of them a good value $(0.860)$ 
Table 4 Results of the Cronbach's Alpha coefficient to analyse the internal consistency of the questionnaire

\begin{tabular}{lc} 
& Cronbach's Alpha \\
\hline $\begin{array}{l}\text { All variables: } \\
98 \text { variables }\end{array}$ & 0.848 \\
$\begin{array}{l}\text { Part 1: } \\
49 \text { variables }\end{array}$ & 0.860 \\
$\begin{array}{l}\text { Parte 2: } \\
49 \text { variables }\end{array}$ & 0.907 \\
\hline
\end{tabular}

and in the other one an excellent value (0.907).

\subsection{Results of the Dimensional Factor Analysis}

\subsubsection{Dimension Topic and Reasons for Innovation}

In the initial analysis, the innovation initiation variable At the initiative of the Management Team obtained a very low extraction communality with a value of 0.492 , so it was decided to eliminate it from the analysis. From the variables associated with this dimension, a matrix defined by 5 factors is obtained that explain $75.3 \%$ of the variance (KMO index $=0.560$, Bartlett's spherity test $\mathrm{P}<0.001)$. Examining the sedimentation graph, the inflection point at which the slope stops decreasing is located from the sixth eigenvalue, so it is confirmed that only the first five factors should be extracted. From the factorial structure matrix obtained with the principal component analysis extraction method, the correspondence between each variable and each of the extracted factors is inferred. Thus, factor 1 could be called "Social cohesion", including the variables "Improvement of the coexistence of the school", "Equal opportunities", "Attention to diversity and Promotion of the entrepreneurial spirit". Factor 2, called "Interaction with the community", includes the variables "Interaction family-community-school", "Due to the need to prepare or modify documents of the school" and "Due to continuing a training course or work group". Factor 3 would include the variables "Exclusive ICT integration" and "Due to sensitivity to the didactic use of ICT exclusively", and, therefore, we will call it "Information and Communication Technologies Exclusively". Factor 4, which includes the variables "Educational success of the students" and "Due to the detection of the needs of the school or of the students", would be called "Success of the school and the students". Finally, factor 5, which includes the variables "Key competences" and "Active methodologies" would be renamed "New methodologies".

\subsubsection{Dimension Type of Innovation}

The values of the communities initially assigned to the variables included in this dimension and those reproduced by the factorial solution using the method of extraction of analysis of the main factors showed that the variable "Introduction or modification of priorities in the objectives of the school" only reproduces $54.4 \%$ of the original variability, while the variable 
"Improvement of the relationships of the members of the school" reproduces $76.3 \%$ of the original variability.

From these variables, a matrix is obtained and defined by 2 factors that explain $67.4 \%$ of the variance (KMO index $=0.726$, Bartlett's spherical test $\mathrm{P}<0.001)$. The sedimentation graph confirmed the number of factors. From the factor structure matrix (Table 5), the correspondence between each variable and each of the extracted factors can be deduced. Thus, factor 1 could be called "Improvement of relations" and factor 2, called "Spatial-temporal changes".

Table 5 Matrix of the structure of the rotated factors corresponding to the dimension Type of innovation

Rotated factor matrix

\begin{tabular}{|c|c|c|}
\hline & \multicolumn{2}{|c|}{ Factors } \\
\hline & 1 & 2 \\
\hline Change in the school values or ideology & 0.173 & 0.808 \\
\hline Variations in the distribution of spaces, in methodology and/or grouping of students & -0.073 & 0.839 \\
\hline Introduction or modification of priorities in the school objectives & 0.658 & 0.333 \\
\hline Improving relations between members of the school & 0.874 & 0.000 \\
\hline Integration of new members (teachers or students) into the school & 0.807 & 0.279 \\
\hline Improving relations with other schools and/or the community & 0.795 & -0.030 \\
\hline Reduction or increase in units and/or teacher-student ratio & 0.500 & 0.638 \\
\hline
\end{tabular}

\subsubsection{Dimension Approach}

Once the values of the communalities initially assigned to the variables and those reproduced by the factorial solution have been calculated according to the method of extraction of analysis of the main factors, it can be seen that the majority presents a high level of extraction communality. From the variables associated with the dimension "Approach", a matrix defined by 6 factors is obtained that explains $72 \%$ of the variance (index of $\mathrm{KMO}=0.589$, Bartlett's spherical test $\mathrm{P}<0.001$ ). Results are corroborated by the sedimentation graph.

The correspondence between each variable and each one of the extracted factors, that is to say, the matrix of factor structure, obtained with the method of extraction of analysis of main components, is shown in table 6. Thus, factor 1 would be called Resources and Management Team, factor 2 would be called Materials and participation of the families, factor 3 would be called Lack of time and indifference of the Management Team, factor 4 would be called Involvement and research, factor 5 would be called Training weaknesses and finally factor 6 would be called Training and concern for the students.

\subsubsection{Dimension Time Devoted to Innovation}

In this dimension, which consists of only 3 variables, the KMO index $<0.5(0.457)$ and the Bartlett's spherical test $\mathrm{p}>0.05(0.129)$ show that there is no logic in carrying out the factorial analysis. 
Table 6 Structure matrix of the rotated factors corresponding to the dimension Approach

Rotated factor matrix

\begin{tabular}{|c|c|c|c|c|c|}
\hline & \multicolumn{5}{|c|}{ Factors } \\
\hline & 1 & 2 & 3 & 4 & 5 \\
\hline $\begin{array}{l}\text { Coordinators are enthusiastic and encourage collaboration between teach- } \\
\text { ers }\end{array}$ & 0.453 & 0.113 & 0.438 & 0.432 & 0,839 \\
\hline All team members are actively involved in the development of innovation & 0.461 & 0.306 & 0.226 & 0.137 & 0,627 \\
\hline Some of the teachers are also researchers & -0.003 & 0.132 & 0.109 & -0.027 & 0,058 \\
\hline Related to economic, material or personal resources & 0.640 & 0.353 & 0.167 & -0.075 & 0,026 \\
\hline Related to lack of time & 0.156 & -0.007 & 0.758 & 0.055 & 0,036 \\
\hline Motivated by the inadequeate training of the teachers themselves & 0.051 & 0.141 & 0.501 & -0.009 & $-0,029$ \\
\hline Related to student response & 0.293 & 0.142 & 0.409 & -0.593 & $-0,041$ \\
\hline Development of curriculum materials related to innovation & 0.367 & 0.615 & -0.257 & 0.350 & $-0,378$ \\
\hline Observations on applications in the classroom of aspects of innovation & -0.011 & 0.860 & 0.007 & 0.163 & 0,126 \\
\hline $\begin{array}{l}\text { Attendance at conferences or official training activities (courses, confer- } \\
\text { ences, among others) by experts in the field of innovation }\end{array}$ & 0.130 & 0.219 & 0.123 & 0.682 & 0,452 \\
\hline Innovation coordination and management & 0.704 & 0.003 & -0.165 & -0.102 & $-0,092$ \\
\hline Diffusion of the innovation & 0.804 & 0.175 & 0.030 & 0.096 & 0,03 \\
\hline Indifference/inhibition to innovation & -0.444 & 0.053 & 0.701 & -0.015 & 0,222 \\
\hline $\begin{array}{l}\text { They are aware of its existence and have not shown much interest or oppo- } \\
\text { sition to it }\end{array}$ & 0.539 & -0.257 & 0.061 & 0.326 & $-0,055$ \\
\hline $\begin{array}{l}\text { They are aware of its existence, are satisfied with it and show interest in } \\
\text { being informed and participating }\end{array}$ & 0.130 & 0.687 & 0.362 & -0.173 & $-0,095$ \\
\hline They know of its existence and oppose its implementation & 0.026 & -0.067 & 0.018 & 0.103 & $-0,066$ \\
\hline
\end{tabular}

\subsubsection{Dimension Resources}

Analyzing the community values of this dimension, the lowest community is presented by the variable "Other schools' staff", with $52.6 \%$ of the original variability while the highest is "Expert advice" with $83.8 \%$ of the original variability. From the variables associated with the "Resources" dimension, a matrix is obtained and defined by 5 factors that explain $72.3 \%$ of the variance (index of $\mathrm{KMO}=0.510$, Bartlett's spherical test $\mathrm{P}<0.001$ ). Examining the sedimentation graph, it is confirmed that only the first five factors should be extracted.

From the factor structure matrix (Table 7) obtained with the principal component analysis extraction method, the correspondence between each variable and each of the extracted factors is deduced. Thus, factor 1 could be called "Teacher's personal resources and material", factor 2 called "Other professionals and student material", factor 3 called "Experts and no funding", factor 4 "Audiovisuals and computer" and factor 5 called "Teachers and management team".

Table 7 Structure matrix of the rotated factors corresponding to the Dimension Resources

Rotated factor matrix

\begin{tabular}{|c|c|c|c|c|c|}
\hline & \multicolumn{5}{|c|}{ Factors } \\
\hline & 1 & 2 & 3 & 4 & 5 \\
\hline Teachers & 0,029 & 0,119 & $-0,094$ & -0.189 & 0.432 \\
\hline Management team & $-0,273$ & 0,243 & 0,526 & -0.135 & 0.137 \\
\hline Schools' psychologists & 0,16 & 0,798 & 0,107 & 0.114 & -0.027 \\
\hline
\end{tabular}




\section{Rotated factor matrix}

\begin{tabular}{|c|c|c|c|c|c|}
\hline $\begin{array}{l}\text { Other professionals in the school, if any (special education } \\
\text { needs team, physiotherapist, nurse, monitors, others) }\end{array}$ & 0,16 & 0,871 & $-0,103$ & 0.251 & -0.075 \\
\hline Students & 0,875 & 0,079 & $-0,159$ & 0.093 & 0.055 \\
\hline Families & 0,835 & 0,193 & $-0,196$ & 0.626 & -0.009 \\
\hline Other school staff & 0,65 & 0,014 & 0,161 & 0.382 & -0.593 \\
\hline Textbooks and/or specialized books & 0,638 & 0,233 & 0,208 & 0.220 & 0.350 \\
\hline Audiovisual resources & 0,143 & 0,214 & 0,049 & -0.158 & 0.163 \\
\hline Teacher-made or students-made materials & 0,658 & $-0,095$ & $-0,022$ & 0.207 & 0.682 \\
\hline Materials from other schools and/or other innovation projects & 0,776 & $-0,152$ & 0,125 & 0.133 & -0.102 \\
\hline Internet and computer programmes & $-0,133$ & $-0,044$ & $-0,102$ & -0.083 & 0.096 \\
\hline $\begin{array}{l}\text { Books, written material and consumables (paper, audio/video } \\
\text { tapes, etc.) }\end{array}$ & 103 & 737 & 0,325 & 0.083 & -0.015 \\
\hline $\begin{array}{l}\text { Technical equipment (videos, cameras, computers, tablets, } \\
\text { etc.) }\end{array}$ & $-0,363$ & 0,635 & 0,393 & 0.164 & 0.326 \\
\hline Expert advice & 0,212 & 0,046 & 882 & 0.162 & -0.173 \\
\hline No funding has been provided & 0,218 & $-0,387$ & $-0,643$ & 0.870 & 0.103 \\
\hline
\end{tabular}

\subsubsection{Dimension Outside Support}

This dimension consists of only 4 variables and the KMO index is less than 0.5 (0.426), so even though Bartlett's spherical test shows a value of $\mathrm{p}<0.05$ (0.031), it does not make sense to perform the factorial analysis. Besides its extraction, the result of two factors does not manage to explain $60 \%$ of the total variance $(58 \%)$.

\subsubsection{Dimension Assessment}

In the initial analysis the variable "The entire educational community" obtained a communal extraction of 0.288 so it was decided to eliminate it from the analysis. From the variables associated with the "Evaluation" dimension, the matrix is defined by 4 factors, which explains $69.15 \%$ of the variance (index of $\mathrm{KMO}=0.510$, Bartlett's spherical test $\mathrm{P}<0.001$ ). From the sedimentation graph, it can be seen that only the first four factors should be extracted.

The factor structure matrix (Table 8) is obtained using the main component analysis extraction method, and from it the correspondence between each variable and each of the extracted factors can be inferred. Thus, factor 1 could be called "Type of assessment", factor 2 "Evaluators", factor 3 "External assess" and finally factor 4 "Timing of assessment".

\subsubsection{Dimension Obstacles}

Following the analysis of the values of the communalities initially assigned to the variables and those reproduced by the factorial solution according to the method of extraction of analysis of the main factors, the variable "Lack of support from the families of the pupils in the centre" obtained an extraction communality of 0.338 , so it was decided to eliminate it from the analysis. Once the analysis was repeated without this variable, a matrix defined by 
Table 8 Structure matrix of the rotated factors corresponding to the dimension Assessment

Rotated factor matrix

\begin{tabular}{|c|c|c|c|c|}
\hline & \multicolumn{4}{|c|}{ Factors } \\
\hline & 1 & 2 & 3 & 4 \\
\hline Self-assessment performed by the innovation team & 0,49 & $-0,543$ & 0,114 & 0,111 \\
\hline One member of the group carries out the entire assessment & 0,059 & 0,878 & 0,032 & 0,032 \\
\hline Assessing other teachers who are not involved in innovation & 0,309 & 0,779 & 0,233 & $-0,202$ \\
\hline External assessment & $-0,075$ & 0,23 & 0,805 & $-0,057$ \\
\hline Direct observation during class time & 0,833 & 0,043 & $-0,127$ & 0,095 \\
\hline Questionnaires, interviews and/or recordings & 0,547 & $-0,015$ & 0,56 & $-0,034$ \\
\hline Written reports & 0,018 & $-0,058$ & 0,829 & 0,194 \\
\hline Group meetings & 0,785 & 0,08 & 0,068 & 0,04 \\
\hline Assess only at the end of the project & $-0,015$ & 0,075 & $-0,022$ & $-0,881$ \\
\hline $\begin{array}{l}\text { Assess at the beginning, during the process through regular meetings and } \\
\text { at the end }\end{array}$ & 0,471 & $-0,105$ & 0,111 & 0,746 \\
\hline $\begin{array}{l}\text { The evaluation has been carried out during the process, but the need for } \\
\text { changes in innovation has not been detected }\end{array}$ & $-0,263$ & 0,46 & 0,053 & 0,451 \\
\hline
\end{tabular}

4 factors of the variables associated with the dimension "Obstacles" was obtained, explaining $76.82 \%$ of the variance (index of $\mathrm{KMO}=0.515$, Bartlett's spherical test $\mathrm{P}<0.001$ ). The sedimentation graph confirms the results obtained.

Analysing the factor structure matrix (Table 9) obtained with the principal component analysis extraction method, the correspondence between each variable and each of the extracted factors is inferred. Thus, factor 1 could be called Excessive time spent and lack of staff continuity, factor 2 Complexity, factor 3 Fear and lack of experience and finally and factor 4 Doubts about whether it is worth it.

Table 9 Rotated factor structure matrix for the dimensión Obstacles

Rotated factor matrix

\begin{tabular}{|c|c|c|c|c|}
\hline & \multicolumn{4}{|c|}{ Factors } \\
\hline & 1 & 2 & 3 & 4 \\
\hline Hours spent working on the innovation outside school were unpaid & 0.815 & 0.113 & 0.199 & 0.022 \\
\hline The scope and complexity of the innovation & 0.199 & 0.875 & 0.136 & -0.072 \\
\hline The paperwork and bureaucracy involved & 0.811 & 0.262 & -0.031 & -0.075 \\
\hline $\begin{array}{l}\text { Lack of experience, commitment and/or dedication of teachers in innova- } \\
\text { tion management }\end{array}$ & 0.137 & 0.177 & 0.862 & -0.044 \\
\hline Fear of going outside the comfort zone of the daily routine & -0.021 & -0.231 & 0.784 & 0.285 \\
\hline Doubts about whether it is really worth the effort & 0.041 & 0.081 & 0.184 & 0.875 \\
\hline $\begin{array}{l}\text { Some members of the innovating team who began the innovation were no } \\
\text { longer at the school }\end{array}$ & 0.681 & -0.397 & -0.065 & 0.404 \\
\hline $\begin{array}{l}\text { The specific characteristics of the school's students make innovation man- } \\
\text { agement difficult }\end{array}$ & 0.017 & 0.680 & -0.295 & 0.420 \\
\hline
\end{tabular}




\subsubsection{Dimension Satisfaction}

From the factor structure matrix, which is obtained with the main component analysis extraction method, the correspondence between each variable and each of the extracted factors is concluded. As we only have 1 factor, we could call it "Satisfaction".

\subsubsection{Dimension Impact}

Within this dimension, the variable "On school materials and equipment" stands out from the rest, as it reproduces almost $86 \%$ of its original variability. From the variables associated with this dimension, a matrix is obtained and defined by 2 factors that explain $70 \%$ of the variance (KMO index $=0.766$, Bartlett's spherical test $\mathrm{P}<0.001)$. The analysis of the sedimentation chart confirms the results. From the factor structure matrix (Table 10), the correspondence between each variable and each one of the factors extracted in this way is concluded. The factor 1 has been called "Changes in the students and school community" and the factor 2 "Changes in the equipment".

Table 10 Rotated factor structure matrix for the satisfaction dimension

Rotated factor matrix

Factor

1

The personal challenges I set myself with innovation management have been covered

0,819

Innovation management has made it easier for me to teach

0,837

The school values the innovation management developed

0,685

Innovation management has provided successful relationships, both personally and professionally

0,796

I am proud to have carried out innovation management

0,879

\subsubsection{Dimension Dissemination}

Finally, under this dimension the $\mathrm{KMO}$ index is 0.688 and the Bartlett's spherical test $\mathrm{P}<0.05$. However, from this analysis only one factor does not manage to explain $60 \%$ of the total variance (56\%) so it does not make statistical sense to carry out the analysis.

In summary (Table 11), this factorial analysis, which will define and influence the management of teaching innovation, has made it possible to group together and reduce the number of variables that define an innovation, which is useful due to the complex relationship among variables and their association.

Table 11 Summary of the factorial analysis of the ICT educational innovations

Social cohesion

School community interactioon
Improvement in the coexistence of the school

Equal opportunities

Attention to diversity

Promotion of the entrepreneurial spirit

Interaction family-community-school

Due to the need to prepare or modify school documents 


\section{ICT exclusively}

School success

New methodologies

Relations improvement

Spatial-temporal changes

Resources and management team

Materials and families implications

Lack of time and indiference of the management team

Involvement and research

Training weakness

Training and concern for the student

Teacher personel, resources and material

Other professionals and students material

Experts and no funding

Audiovisual and computer

Teachers and management team

Type of assessment

Evaluators

Externally assessed
Due to continuing a training course or work group

Due to sensitivity to the didactic use of ICT exclusively

Educational success of the students

Due to the detection of the needs of the school or of the students

Key competences

Active methodologies

Introduction or modification of priorities in the objectives of the school

Improvement in the relationships of the members of the school

Integration of new members into the school

Improving relations with other schools and/or the community

Change of the school's values or ideology

Variations in the distribution of spaces, in methodology and/or grouping of students

Reduction or increase of units and/or teacher/student ratio

Economic, material or personal resources

Management's team involvement has been innovation coordination

Families know about innovation and are satisfied and show interest in it

Development of curriculum materials related to innovation

Families know about innovation and are satisfied and show interest in it

Related to lack of time

Management team show indifference and inhibition towards innovation

All team members are actively involved in the development of innovation

Some of the teachers are also researchers

Motivated by the inadequate training of the teachers themselves

Families know about innovation and are opposing its development

Related to student response

Attendance at conferences or official training activities

Students

Families

Other school staff

Textbooks and/or specialized books

Teacher-made materials

Materials from other schools and/or other innovation projects

School psychologists

Other professionals in the school

Books, written material and consumables

Technical equipment

Expert advice

No funding has been provided

Audio-visual resources

Internet and computer programs

Teachers

Management team

Direct observation during class time

Questionnaires, interviews and/or recordings

Group meetings

Self-assessment performed by the innovation team

One member of the group carries out the entire assessment

Assessing other teachers who are not involved in innovation

External assessment 


\begin{tabular}{|c|c|}
\hline \multirow{3}{*}{ Timing of assessment } & Written reports \\
\hline & Assess only at the end of the project \\
\hline & $\begin{array}{l}\text { Assess at the beginning, during the process through regular meetings and at the } \\
\text { end }\end{array}$ \\
\hline \multirow[t]{2}{*}{ Excessive time spent and lack of staff continuity } & The time spent working on the innovation outside school hours was unpaid \\
\hline & $\begin{array}{l}\text { Some members of the innovation team who began the innovation were no longer } \\
\text { at the school }\end{array}$ \\
\hline \multirow{3}{*}{$\begin{array}{l}\text { Complexity } \\
\text { Fear and lack of experience }\end{array}$} & The paperwork and bureaucracy involved \\
\hline & The scope and complexity of the innovation \\
\hline & $\begin{array}{l}\text { Lack of experience, commitment and/or dedication of teachers in innovation } \\
\text { management }\end{array}$ \\
\hline Doubts about whether its worthwhile & Doubts about whether it its really worth the effort \\
\hline \multirow[t]{4}{*}{ Satisfaction } & $\begin{array}{l}\text { The personal challenges I set myself with innovation management have been cov- } \\
\text { ered }\end{array}$ \\
\hline & $\begin{array}{l}\text { Innovation management has provided successful relationships, both personally } \\
\text { and professionally }\end{array}$ \\
\hline & The school values the innovation management developed \\
\hline & Changes have an effect on the teaching-learning processes \\
\hline \multirow[t]{3}{*}{ Changes in the students and school community } & Changes have an effect on the family-community-school interactions \\
\hline & Changes have an effect on school spaces and timing organization \\
\hline & Changes have an effect on student's motivation \\
\hline Changes in the equipment & Changes have an effect on school materials and equipment \\
\hline
\end{tabular}

\section{DISCUSSION AND CONCLUSIONS}

The absence of cross-validated instruments that measure the innovations in schools, makes it difficult to assess them and challenges our common understanding of what causes innovations in schools to ultimately fail or succeed (Lambriex-Schmitz et al., 2020). The use of quantitative validation techniques allows us to present an instrument that fulfills this purpose. Unable to find other related instruments, we believe that the "MANEDUIN" questionnaire represents a contribution to research in the field of educational validation.

Results obtained with our questionnaire show high reliability and validity, so we can state it is suitable to measure innovation management in primary and pre-primary schools. Cronbach's Alpha value obtained shows that the questionnaire demonstrates internal consistency and that the factorial analysis corroborates the dimensions proposed in the design of the questionnaire, confirming the validity of the construct. Considering the previous results (Einola \& Alvesson, 2021; Gairín et al., 2010; Gobo \& Mauceri, 2014; Jauregui et al., 2012; Marcelo et al., 2009), the successful use of this type of questionnaire to evaluate the management of educational innovations is evidenced. In its practical application, the questionnaire behaviour was satisfactory. In addition, it was easy to administer, correct and provide an appropriate analysis of the dimensions under study. It also approximates the technical dimensions of other questionnaires such as those indicated by the authors (GarcíaMartín \& Cantón-Mayo, 2020; Lucas, Rodríguez, \& Mayo, 2020; Lueg \& Vila, 2016).

However, it is important not to lose sight of the fact that the relationship between variables is complex and their association, as shown by the factor analysis in the questionnaire, 
will define and directly influence teaching innovation. Likewise, this analysis has made it possible to group together and reduce the number of variables that define an innovation.

There is a high saturation rate found in the factor components when the analysis is done separately for each of the dimensions. As the questionnaire was so long, it was not possible to carry out a general factor analysis, which explains the choice of the dimensions. It is worth noting that the personal aspects are the most significant and the institutional aspects are the least important in almost all the factors analyzed.

Satisfaction and obstacles are highly sensitive to the social dimension, more than to the individual one, and represent a decisive pillar in the management of innovations in schools, which must be promoted, understood and managed in the first case and reasoned, convinced and deactivated in the second. These aspects have already been highlighted with slight nuances in other studies (Mayo, Martínez, \& S, 2017).

Although the results of the present study show consistent reliability and validity, it is necessary to show some of the limitations. We are aware of the weaknesses of the questionnaire in reconstructing a reality as complex and full of relationships, attitudes and implicit meanings as that of education (Buendía \& Alba, 1994; Einola \& Alvesson, 2021; Hardy \& Ford, 2014).

Some other limitations are the high number of questionnaires that may be lost when sent by mail and the tendency of subjects to give answers that are considered socially correct. These are frequent issues in studies by questionnaire (Anguita, Labrador, \& Campos, 2003; Einola \& Alvesson, 2021). Besides, we should mention that the questionnaire designed, while providing insightful information on the issues examined here, was somewhat biased in terms of the variables examined and participating teachers. Thus, not all the questionnaire items were applicable to all teachers or schools. It would also be interesting to increase the study population to confer its comparisons greater statistical power.

Nevertheless, the good psychometric properties of this questionnaire make it advisable to use it to measure the management of educational innovations that take place in preprimary and primary schools. It may be interesting for any future research to expand the sample and apply the questionnaire to other provinces and communities, with the aim of improving knowledge and dissemination of the innovations and thus advance towards real educational change.

In accordance with the results presented, the questionnaire can be approved for application in practice to measure different dimensions of educational innovations. Therefore, the measurement instrument reported in this article provides a valuable starting point for further testing. The survey validated in this study is a powerful tool for analyzing the current situation of the Spanish educational system with regard to the management of educational innovations. The questionnaire provides a general description, which goes beyond previous questionnaires aimed at specific areas of evaluation or at specific administrative or management aspects.

As future lines of research, further replication of this study should be undertaken in other educational contexts to achieve more comprehensive levels of agreement about the reliability and validity of the instrument. Finally, it is important to emphasize the need to initiate 
new research, since there is still a need for studies designed to assess the innovations undertaken by the different education contexts with an approach adapted to each environment, as well as the dissemination of such experience both nationally and internationally.

\section{REFERENCES}

Aguilar, G., Eduardo, H., \& Berganza, C. E. (1996). Self-esteem and depression in Guatemalan adolescents. Revista Latinoamericana de Psicología, 28(2), 341-366.

Almandoz, M. R. (2008). Management of innovations in secondary education. Santillana-Serie Aula $\mathrm{XXI} / \mathrm{OEI}$.

Anguita, J. C., Labrador, J. R. R., \& Campos, J. D. (2003). Surveys as a research technique. Composition of questionnaires and statistical processing of data (I). Atención Primaria, 31(8), 527-565. https://doi.org/10.1016/S0212-6567(03)70728-8

Bakhru, K. M. (2018). Aligning teaching methods for learning outcomes: a need for educational change in management education using quality function deployment approach. International Journal of Learning and Change, 10(1), 54-69. https://doi.org/10.1504/IJLC.2018.089533

Batllé, R. (2015). Teachers do great things in unfair anonymity. [Blog post]. Retrieved from https:// bit.ly/3frlLDQ

Berrocoso, J. V., Arroyo, M. C. G., \& Diaz, M. J. S. (2010). Educational policies for the ICT integration in Extremadura and their effects about innovation and teaching-learning process: teachers' perceptions. Revista de Educación, 352, 99-124.

Bocconi, S., Kampylis, P., \& Punie, Y. (2012). Innovating Learning: Key Elements for Developing Creative Classrooms in Europe. EUR 25446 EN. Publications Office of the European Union.

Buendía, J., \& Alba, V. (1994). Aging and heaths psycohology. Siglo XXI.

Carbonell, J. (2015). XXI century's pedagogies. Alternatives for educational innovation. Octaedro.

Cattell, R. B. (1966). The meaning and strategic use of factor analysis. Handbook of multivariate experimental psychology. Rand McNally.

Cerrillo, Q. M. M.-M. (2000). Leaders' dilemmas in the face of innovation. In A. Estebaranz (Ed.), Building change: perspective and proposals for educational innovation (pp. 393-410). Universidad de Sevilla. Retrieved from https://bit.ly/3d0YZkR

Cuenca, L. G., Gorospe, J. M. C., Aberasturi, E. J. D., \& Etxebarria, A. I. (2009). The reflexive model in teacher training and narrative thinking: study of a case of educational innovation in the Teaching Practicum. Revista de Educación, 350, 493-505.

Einola, K., \& Alvesson, M. (2021). Behind the Numbers: Questioning Questionnaires. Journal of Management Inquiry, 30(1), 102-114.

Evans, R., \& Leppmann, P. (1970). Resistance to Innovation in Higher Education. Jossey-Bass Publishers Inc.

Ferrando, P. J., \& Anguiano-Carrasco, C. (2010). El análisis factorial como técnica de investigación en psicología. Papeles del Psicólogo, 31(1), 18-33.

Frías-Navarro, D., \& Soler, M. (2012). Exploratory factor analysis (EFA) practices in consumer behavior and marketing research. Suma Psicológica, 19, 45-58.

Gairín, J., Armengol, C., \& Moreno, J. L. M. (2010). Educational innovation in the Autonomous communities of Catalonia and Aragon. Revista del Curriculum y Formación del Profesorado, 14(1).

García-Martín, S., \& Cantón-Mayo, I. (2020). Validation of a questionnaire to evaluate the use of technologies for knowledge management in secondary school students. Revista Fuentes, 21(2), 16-28. http://doi.org/10.12795/revistafuentes 
George, D., \& Mallery, P. (2003). SPSS for Windows step by step: A Simple Guide and Reference. 11.0 Update (4th ed.). Allyn \& Bacon.

Gibbons, S., \& Silva, O. (2011). School quality, child well-being and parents' satisfaction. Economics of Education Review, 30(2), 312-331. https://doi.org/10.1016/j.econedurev.2010.11.001

Gobo, G., \& Mauceri, S. (2014). Constructing survey data: An interactional approach. Sage.

Halász, G. (2021). Measuring innovation in education with a special focus on the impact of organizational characteristics. Hungarian Educational Research Journal, 23-27. https://doi.org/ 10.1556/063.2021.00032

Hardy, B., \& Ford, L. R. (2014). It's not me, it's you: Miscomprehension in surveys. Organizational Research Methods, 17(2), 138-162. https://doi.org/10.1177/1094428113520185

Hoffman, A., \& Holzhuter, J. (2012). The evolution of higher education: innovation as natural selection. In A. Hoffman \& S. Spangehl (Eds.), Innovation in Higher Education: Igniting the Spark for Success (pp. 3-15). American Council on Education/Rowman \& Litttlefield Publishers Inc.

Jauregui, A., \& P. (2010). Educational innovation in the Basque Country: inclusion, equity and European integration. Revista de curriculum y formación del profesorado, 14(1), 135-152.

Jauregui, A., Vidales, P. B., \& K. (2012). Educational innovation in Cantabria and the Basque Country: a comparative study. Revista de Pedagogía, 64(1), 39-58.

Jimenez, G., Flores, E. G., Gómez, J. R., \& G. (2000). Factorial analysis. Cuadernos de Estadística, 7.

Lambriex-Schmitz, P., Van Der Klink, M. R., \& Beausaert, S. (2020). Towards successful innovations in education: Development and validation of a multi-dimensional Innovative Work Behaviour Instrument. . Vocations and Learning, 13, 313-340. Retrieved from https://doi.org/10.1007/ s12186-020-09242-4

Law, N., Yuen, A., \& Fox, R. (2011). Educational innovations beyond technology-Nurturingleadership and establishing learning organizations. Springer.

Ledesma, R., Ibañez, G. M., \& Mora, P. V. (2002). Internal consistency analysis by means of Cronbach's Alpha: a computer program based on dynamic graphics. Psico-USF, 7(2), 143-152. https://doi.org/10.1590/S1413-82712002000200003

Licht, A. H., Tasiopoulou, E., \& Wastiau, P. (2017). Open Book of Educational Innovation. European Schoolnet.

Lucas, E. F. D., Rodríguez, M. S. G., \& Mayo, I. (2020). Assessment of Knowledge Management and Satisfaction in Future Teachers. Aula Abierta, 49(1), 75-82. https://doi.org/10.17811/ rifie.49.1.2020.75-82

Lueg, C. F., \& Vila, R. R. (2016). Diseño y validación de una escala de autoevaluación de competencias digitales para estudiantes de pedagogía. Revista de Medios y Educación, 48, 209-224.

Marcelo, C., Aramendi, P., Arencibia, S., Armengol, C., Ayala, C., Cotillas, C., et al. (2009). Study on educational innovation in Spain. Government of Spain, Ministry of Education, Institute of Teacher Training, Educational Research and Innovation (IFIIE)/National Center for Innovation and Educational Research (CNIIE).

Marcus, J. (2012). Old school: four-hundred years of resistance to change. In B. Wildavsky, A. Kelly, \& K. Carey (Eds.), Reinventing Higher Education: The Promise of Innovation (pp. 41-72). Harvard Education Press.

Martín, S. C., González, M., \& Costillas, L. N. (2013). Educational innovation in schools. Revista Galego-Portuguesa de Psicoloxía e Educación, 21(1).

Mayo, C., Martínez, I. T., \& S. (2017). Satisfaction in the professional performance of Pre-Primary and Primary Education teachers. A case study. Profesorado. Revista de Currículum y Formación de Profesorado, 21(4), 279-292.

Muñoz-Repiso, A. G.-V., Martín, S. C., \& Gómez-Pablos, V. B. (2020). Validation of an Indicator Model (INCODIES) for Assessing Student Digital Competence in Basic Education. Journal of 
New Approaches in Educational Research, 9(1), 110-125. https://doi.org/10.7821/naer.2020.1 .459

OECD. (2013). Innovative Learning Environments, Educational Research and Innovation. OECD Publishing. http://doi.org/10.1787/9789264203488-en

OECD. (2017). Handbook for innovative learning environments. OECD Publishing. https://doi.org/ 9789264277274-en

Ortega, A., Sicilia, A., \& González-Cutre, D. (2013). Preliminary validation of the Parent-Initiated Motivational Climate Questionnaire-2 (PIMCQ-2). Revista Latinoamericana de Psicología, 45(1), 35-45.

Paniagua, A., \& Istance, D. (2008). Teachers as designers of learning environments: the importance of innovative pedagogies. Educational Research and Innovation. OECD Publishing. http:// doi.org/10.787/9789264085374-en

Ramírez-Montoya, M. S. (2020). Challenges for Open Education with Educational Innovation: A Systematic Literature Review. Sustainability, 7053. https://doi.org/10.3390/su1217705

Rikkerink, M., Verbeeten, H., Simons, R. J., \& Ritzen, H. (2016). A new model of educational innovation: Exploring the nexus of organizational learning, distributed leadership, and digital technologies. Journal of Educational Change, 17(2), 223-249. https://doi.org/10.1007/s10833 -015-9253-5

Rochovská, I., Droščák, M., \& Šilonová, V. (2020). Comparison of Preferred Didactic Forms and Methods in Homeschooling. The New Educational Review, 61(3), 13-25.

Rodríguez, M. U., Cantabrana, J. L. L., \& Cervera, M. G. (2021). Validation of a tool for selfevaluating teacher digital competence. Educación XXI, 24(1), 353-373. http://doi.org/10 $.5944 /$ educXX1.27080

Scherbaum, C., \& Meade, A. (2009). Measurement in the organizational sciences: conceptual and technological advances. The SAGE handbook of organizational research methods (pp. 636-653). Sage.

Serdyukov, P. (2017). Innovation in education: what works, what doesn't, and what to do about it. Journal of Research in Innovative Teaching \& Learning, 10(1), 4-33. https://doi.org/10.1108/ JRIT-10-2016-0007

Tójar, J. C., \& Mena, E. (2011). Educational innovations in the Andalusian context. Multicase analysis of experiences in pre-primary and primary education. Revista de Educación, 354, 499-527.

Turrado-Sevilla, M. A., Mayo, I., \& Lucía, A. (2020). Characterising innovative primary schools and their teachers in Spain. International Journal of Learning and Change, 12(3). https://doi.org/ 10.1504/IJLC.2020.108371

Vincent-Lancrin, S., Urgel, J., Kar, S., \& Jacotinet, G. (2019). Measuring innovation in education 2019: What has changed in the classroom. OECD Publishing. https://doi.org/10.1787/ 9789264311671-en

Wiersema, L. D. (2001). Conceptualization and development of the sources of enjoyment in youth sport questionnaire. Measurement in Physical Education and Exercise Science, 5(3), 153-157. https://doi.org/10.1207/S15327841MPEE0503_3 